\title{
Clemastine Fumarate
}

National Cancer Institute

\section{Source}

National Cancer Institute. Clemastine Fumarate. NCI Thesaurus. Code C47454.

A synthetic ethanolamine with anticholinerg ic, sedative, and histamine $\mathrm{H} 1$ antagonistic properties. Clemastine fumarate blocks the $\mathrm{H} 1$ histamine receptor and prevents the symptoms that are caused by histamine activity on capillaries, bronchial and gastrointestinal smooth muscles, including vasodilation, increased capillary permeability, bronchoconstriction, and spasmodic contraction of gastrointestinal smooth muscles. This drug also prevents histamine-induced pain and itching of mucous membranes. 